\title{
Natural Dye Extracted from Vitex negundo as a Potential Alternative to Synthetic Dyes for Dyeing of Silk
}

\author{
Venkataramanappa Narayana Swamy ${ }^{1} \cdot$ Kurikempanadoddi Ninge Gowda ${ }^{2}$. \\ Rajagopal Sudhakar ${ }^{2}$
}

Received: 15 February 2015/ Accepted: 1 June 2015/Published online: 26 June 2015

(C) The Institution of Engineers (India) 2015

\begin{abstract}
Since the last decade, the application of natural dyes on textile material has been gaining popularity all over the world, possibly because of the increasing awareness of issues concerning the environment, ecology and pollution control. The present paper investigates extraction of natural dye from leaves of the plant Vitex negundo, which is an abundant, cheap, and readily available agricultural by-product. Water extracts from V. negundo was used to dye silk fabrics. Optimum extraction conditions included $\mathrm{pH}$ 9, duration $120 \mathrm{~min}$, and temperature $90^{\circ} \mathrm{C}$. Optimum dyeing conditions included dyeing $\mathrm{pH} 5$ and duration of $60 \mathrm{~min}$. Potash alum, tannic and tartaric acid were used as mordants, all of which are benign to human health and the environment. Color strength and color coordinates in terms of $\mathrm{L}^{*}, \mathrm{a}^{*}, \mathrm{~b}^{*}, \mathrm{C}$, and $\mathrm{h}$ were examined. A range of shades were obtained when fabrics were dyed with different mordants and mordanting techniques. The extracted dye was tested for some of the eco-parameters using atomic absorption spectrophotometry and GC/MS. The test results were compared with set standards to determine the eco-friendliness of natural dye. Their concentrations were found to be lower than the stipulated limits. Dyed samples were tested for antimicrobial activity against gram-positive and gram-negative bacteria. The dyed silk fabrics showed acceptable fastness properties and
\end{abstract}

Venkataramanappa Narayana Swamy gvnnarayan@gmail.com

1 The Oxford College of Science, Bangalore 560 102, Karnataka, India

2 Department of Fashion and Apparel Design, Bangalore University, Bangalore 560 001, Karnataka, India were also found to possess antibacterial activity. It can be concluded that the abundantly available agricultural byproduct $V$. negundo has great potential to be effectively utilized as a natural dye for silk.

Keywords Natural dyeing - Heavy metals - Mordants · Vitex negundo $\cdot$ Antimicrobial activity

\section{Introduction}

Dyeing of textiles using synthetic dyes could have a high negative impact on the environment, as well as on the safety and health of dyers and end-users. Consumers have become more aware of environmental issues; in fact, they are increasingly seeking products with a green or organic label [1]. During the last few decades a growing interest in the use of natural colorants has been evident both in public awareness and scientific activity [2,3]. This increased interest could be on account of the natural dyes' high compatibility with the environment, relatively low toxicity and low allergic effects. Recent debates in favour of natural dyes consider its positive features such as increased sustainability, renewable resources, environmentally friendly processing, reduced pollution, and green chemistry. The demand for more sustainable processes should be seen as a driving force for identifying new strategies that can bring about a revival of natural dyes in textile dyeing.

Vitex negundo (Linn.) is a large, aromatic shrub belonging to the verbenaceae family and grows in waste lands and is commonly cultivated as a hedge plant throughout India. The upper surface of the leaves is green and the lower surface is silvery in color. It is one of the common plants used in traditional medicine and is reported to have a variety of biological uses [4]. The leaves are 
aromatic, bitter, acrid, astringent, anodyne, anti-inflammatory [5], antipyretic or febrifuge, tranquilizer, bronchial smooth muscle relaxant, anti-arthritic, antihelminthic, antibacterial and vermifuge [6, 7]. This plant reportedly showed diverse pharmacological properties such as analgesic, anti-noise receptive, anti-oxidant and anti-hyperglycemic [8]. The major flavonoids present in the leaves are Luteolin-7-glucoside (Fig. 1), casticin (Fig. 2), artemetin (Fig. 3) $[9,10]$ which make it a possible dye candidate for silk fabric. In the present investigation an attempt has been made to extract natural dye from $V$. negundo leaves, evaluate its dyeing potential, color-fastness properties, heavy metal content, and antimicrobial activity.

\section{Experimental Procedure}

\section{Materials}

The degummed mulberry silk fabric (purchased from a trader in Bangalore) weighing $40 \mathrm{~g} / \mathrm{m}^{2}$ with a yarn density of 132 ends/inch and 116 picks/inch was used. The dry leaves of $V$. negundo were collected from the Jnanabharathi campus, Bangalore University. Potassium aluminum sulphate

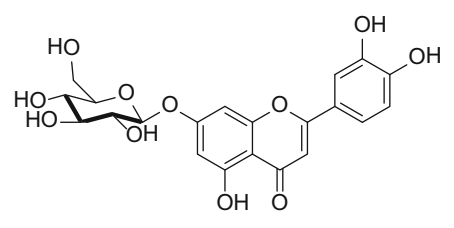

Fig. 1 Luteolin-7-glucoside<smiles>COc1ccc(-c2oc3cc(OC)c(OC)c(O)c3c(=O)c2OC)cc1O</smiles>

Fig. 2 Casticin<smiles>COc1ccc(-c2oc3cc(OC)c(OC)c(OC)c3c(=O)c2O)cc1OC</smiles>

Fig. 3 Artemetin
$\left[\mathrm{KAl}\left(\mathrm{SO}_{4}\right)_{2} \cdot 12 \mathrm{H}_{2} \mathrm{O}\right]$, tannic acid $\left[\mathrm{C}_{76} \mathrm{H}_{52} \mathrm{O}_{46}\right]$, tartaric acid $\left[\mathrm{C}_{4} \mathrm{H}_{6} \mathrm{O}_{6}\right]$ of analytical grade were used as mordants. Distilled water was used for extraction of dye and preparation of chemical solutions.

\section{Dye Extraction}

Fresh Vitex negundo leaves were dried at room temperature till completely dry and then crushed using a mixer grinder and then used as the raw material for dye extraction. Optimization of extraction was performed at different temperatures $\left(30,50,80,90\right.$ and $\left.100{ }^{\circ} \mathrm{C}\right)$ for different $\mathrm{pH}$ $(5,7,8,9$ and 10) and for different durations $(45,60,75,90$ and $120 \mathrm{~min}$ ). The extracted dye was filtered and cooled to room temperature. The dye extracted at optimum conditions was filtered and evaporated using a roto-evaporator and the obtained dye powder was used for dyeing experiments.

\section{Method of Mordanting}

Aluminum potassium sulphate, tannic acid and tartaric acid were used for mordanting silk. Pre- and post-mordanting techniques were used for this study. Pre-mordanting included pre-treatment in a bath containing 5 and $10 \%$ (owf) mordant at an MLR of $1: 40$ at $60{ }^{\circ} \mathrm{C}$ for $30 \mathrm{~min}$ and dried at room temperature and for post-mordanting, the dyed samples were treated with 5 and $10 \%$ (owf) mordants at a MLR ratio of $1: 40$ at $60{ }^{\circ} \mathrm{C}$ for $30 \mathrm{~min}$.

\section{Dyeing}

All dyeings were carried out in a dye bath maintained at $\mathrm{pH}$ 5 containing $10 \%$ dye (owf) at MLR 1:40 in a beaker dyeing machine. The dyeing was started at $40{ }^{\circ} \mathrm{C}$ then the temperature was raised to $90{ }^{\circ} \mathrm{C}$ and dyeing was continued for $60 \mathrm{~min}$. The dyed samples were subsequently rinsed and soaped in $1 \mathrm{gpl}$ nonionic detergent at $70{ }^{\circ} \mathrm{C}$ for $15 \mathrm{~min}$ and dried.

\section{Determination of Exhaustion of Dye}

Dye uptake was determined by measuring the absorbance of the diluted dye bath samples at a wavelength of maximum absorbance $\left(\lambda_{\max } 420 \mathrm{~nm}\right)$ of dye. The percentage of dye bath exhaustion was calculated as follows:

$\%$ Dye exhaustion $=\left[\left(\mathrm{A}_{0}-\mathrm{A}_{1}\right) / \mathrm{A}_{0}\right] \times 100$,

where $\mathrm{A}_{0}$ and $\mathrm{A}_{1}$ are absorbance at a wavelength of maximum absorption $\left(\lambda_{\max }\right)$ of dye bath before and after dyeing. 


\section{Determination of Color Strength and Color Parameters}

Color was evaluated by means of $\mathrm{K} / \mathrm{S}$ and CIELAB color coordinates with illuminant D65/10 $0^{\circ}$ observer on Gretag Macbeth Color Eye 7000 A Spectrophotometer. Four measurements were made for each sample and the reflectance values over a range of $350-750 \mathrm{~nm}$ were recorded. The K/S values were assessed using the Kubelka-Munk equation.

$K / S=(1-R)^{2} / 2 R$,

where $R$ is the observed reflectance at $\lambda_{\max }, K$ is the absorption coefficient, and $S$ is the light scattering coefficient.

The colors are given in CIE Lab co-ordinates, L corresponding to the lightness $(100=$ White, $0=$ Black $)$, ${ }^{*}$ to the red-green co-ordinate (positive sign $=$ red, negative $\operatorname{sign}=$ green $)$ and $b^{*}$ to the yellow-blue co-ordinate (positive $\operatorname{sign}=$ yellow, negative sign $=$ blue). $\mathrm{C}$ is a measure of chroma (saturation) and represents the distance from the neutral axis. $\mathrm{h}$ is a measure of hue and is represented as an angle ranging from $0^{\circ}$ to $360^{\circ}$. Angles that range from $0^{\circ}$ to $90^{\circ}$ are reds, oranges and yellows. $90^{\circ}$ $180^{\circ}$ are yellows, yellow-greens and greens. $180^{\circ}-270^{\circ}$ are greens, cyan and blue. $270^{\circ}-360^{\circ}$ are blue, purples, magentas and return to reds.

\section{Evaluation of Fastness Properties}

The dyed fabrics were assessed for light-fastness according to ISO 105 B02 using Xenotest light-fastness apparatus. Color changes were assessed using the blue wool standards. Wash-fastness was evaluated according to ISO 105 C02 using launderometer. Rubbing-fastness evaluation was performed according to ISO-X12 using crock meter. The change in the color of dyed fabrics and the staining of the adjacent white fabric were evaluated by grey scale standards.

\section{Evaluation of the Antimicrobial Activity}

Escherichia coli (E. coli) a gram-negative bacterium, was selected due to its popularity of being selected as a test organism and its resistance to common antimicrobial agents. Staphylococcus aureus (S. aureus), a pathogenic gram-positive bacterium was used as it causes major crossinfection in hospitals and is the most frequently evaluated species [11].

Circular fabric swatches were tested using $1 \pm 0.1 \mathrm{~mL}$ of bacterial inoculums in a $200 \mathrm{~mL}$ container. The inoculums were a nutrient broth culture containing $1.0 \times 10^{5}$ colony forming units (CFU)/mL of bacteria. For test swatches to be in contact with the bacteria for $24 \mathrm{~h}$, $100 \mathrm{~mL}$ of sterilized distilled water was poured into the vessel and was shaken in a bacterial suspension and the reduction in bacterial activity in standard time was measured $[11,12]$. The efficiency of the antimicrobial treatment was determined by comparing the reduction in bacterial concentration of the treated sample with that of the control sample expressed as a percentage reduction in standard time.

$\mathrm{R}=[(\mathrm{A}-\mathrm{B}) / \mathrm{A}] \times 100$,

where $R$ is the percentage reduction in microbial population; $A$ represents the number of bacteria colonies in the control and $B$ represents the number of bacteria colonies in the treated fabrics.

\section{Determination of Durability of Antimicrobial Activity to Washing}

Antimicrobial activity of dyed samples was evaluated after 1,5 and 10 washing cycles and the durability of antimicrobial property was calculated in terms of per cent retention of antimicrobial activity using the formula given below:

$\%$ Retention of antimicrobial activity $=\frac{\mathrm{R}_{\mathrm{n}}}{R_{0}} \times 100$,

where $R_{0}$ is the per cent of microbial reduction before washing and $R_{n}$ is the per cent of microbial reduction after $\mathrm{n}$ wash cycles.

\section{Elemental Analysis}

Heavy metal concentrations in the digested samples were determined with A6300 Shimadzu flame atomic absorption spectrophotometer with Shimadzu auto sampler (Asc-600). The calibration curves were prepared separately for all the metals by running different concentrations of standard

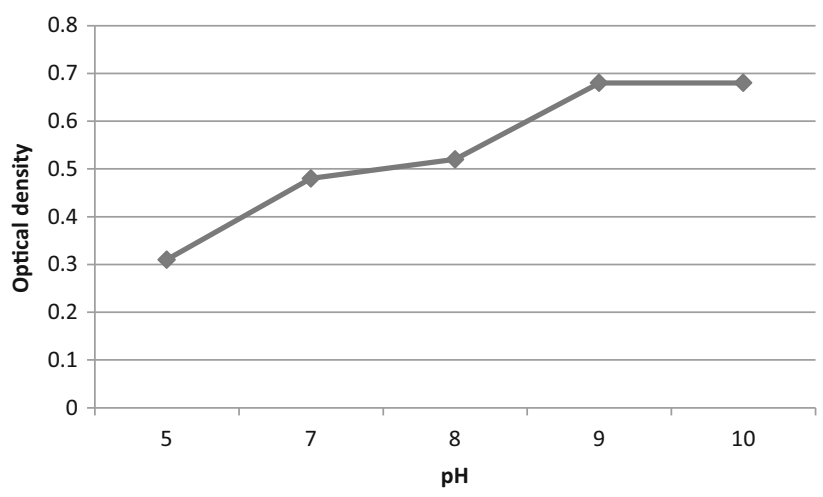

Fig. 4 Effect of $\mathrm{pH}$ on dye extraction 


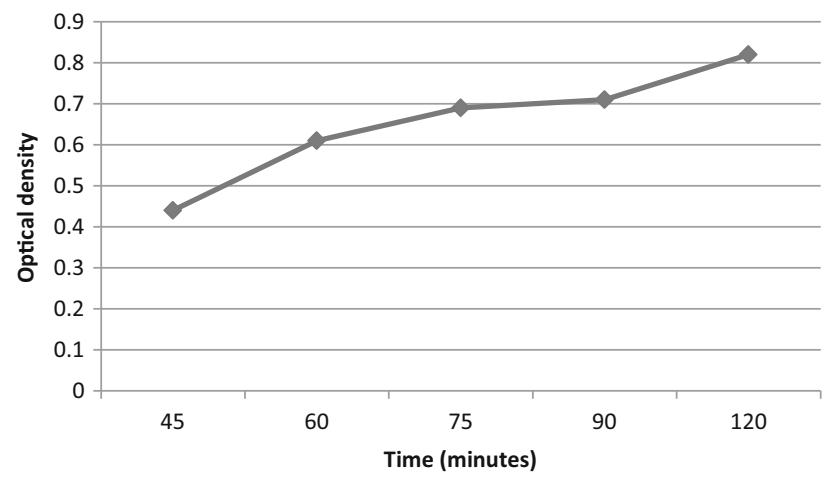

Fig. 5 Effect of duration on dye extraction

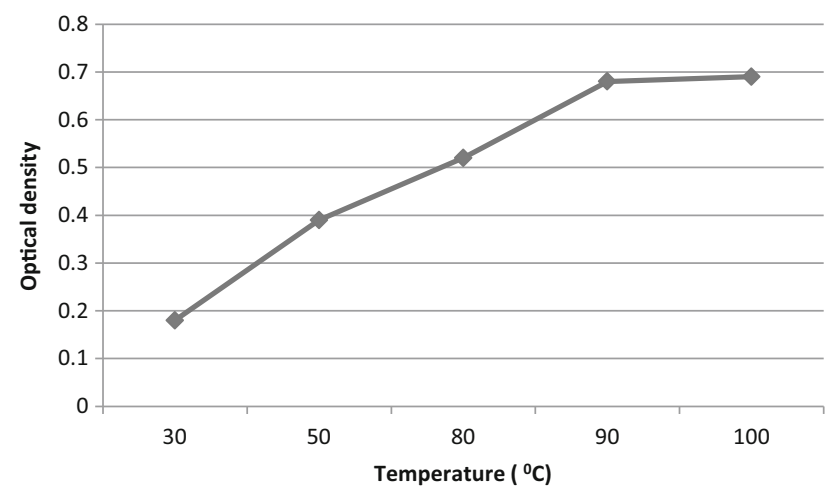

Fig. 6 Effect of temperature on dye extraction

solutions $[13,14]$. The extracted dye was also analyzed for the presence of banned aryl amines after reductive cleavage and isolation using GC/MS.

\section{Results and Discussion}

\section{Dye Extraction Conditions}

Extracts obtained under various conditions were estimated by measuring their absorbance at $420 \mathrm{~nm}$. From several sets of experiments, it was observed that the yield of the dye extract was better at $\mathrm{pH} 9$ (Fig. 4), duration $120 \mathrm{~min}$ (Fig. 5) at $90{ }^{\circ} \mathrm{C}$ temperature (Fig. 6). The amount of dye uptake by silk fabrics dyed with $V$. negundo leaves was expressed as percentage of dye exhaustion and results are shown in Table 1. The maximum exhaustion was observed in the case of tartaric acid samples followed by alum and tannic acid mordanted samples.

\section{Effect of Dyeing Conditions}

Figure 7 shows that the $\mathrm{pH}$ of the dye bath has a considerable effect on the colour strength of silk fabric. With the increase in $\mathrm{pH}$ the colour strength of the dyed fabrics showed a decrease in colour strength indicating acidic $\mathrm{pH}$ to be the ideal for better dye uptake.

Figure 8 shows the effect of dyeing time on the color yield obtained for the dyed fabrics. This figure indicates that the color yield increases as the time increases up to $60 \mathrm{~min}$, and then a plateau is attained after $90 \mathrm{~min}$ up to 150 min. A longer dyeing time means higher color strength until dye exhaustion attains equilibrium and there is no significant increase after further increase in dyeing time. This seems to indicate that silk fabrics reach saturation and do not absorb any more dye.

Table 1 Colorimetric data of silk samples dyed with Vitex negundo leaves extract

\begin{tabular}{|c|c|c|c|c|c|c|c|c|c|}
\hline Mordant & Method & $\%$ Dye exhaustion & Mordant \% & $\mathrm{K} / \mathrm{S}$ & $\mathrm{L}^{*}$ & $a^{*}$ & $\mathrm{~b}^{*}$ & $\mathrm{C}$ & $\mathrm{h}$ \\
\hline Undyed & - & 51 & - & - & 90.53 & 2.25 & 0.15 & 2.18 & 365.75 \\
\hline Control & - & & - & 1.25 & 55.33 & 14.22 & 09.45 & 42.08 & 46.65 \\
\hline \multirow[t]{4}{*}{ Alum } & \multirow[t]{2}{*}{ Pre } & 80 & 5 & 3.34 & 53.81 & 3.13 & 15.82 & 16.13 & 78.80 \\
\hline & & 88 & 10 & 5.70 & 44.71 & 1.51 & 12.50 & 16.93 & 83.01 \\
\hline & \multirow[t]{2}{*}{ Post } & 51 & 5 & 4.01 & 41.68 & 3.52 & 13.61 & 14.08 & 75.49 \\
\hline & & 51 & 10 & 6.97 & 44.57 & 1.32 & 10.13 & 10.22 & 82.53 \\
\hline \multirow[t]{4}{*}{ Tannic } & \multirow[t]{2}{*}{ Pre } & 65 & 5 & 2.83 & 53.43 & 3.85 & 16.21 & 16.66 & 76.62 \\
\hline & & 81 & 10 & 3.05 & 52.98 & 3.69 & 15.88 & 16.30 & 76.91 \\
\hline & \multirow[t]{2}{*}{ Post } & 51 & 5 & 3.68 & 43.87 & 3.70 & 14.12 & 14.60 & 75.31 \\
\hline & & 51 & 10 & 4.16 & 41.38 & 2.81 & 13.39 & 13.68 & 78.14 \\
\hline \multirow[t]{4}{*}{ Tartaric } & \multirow[t]{2}{*}{ Pre } & 86 & 5 & 4.16 & 51.61 & 2.83 & 13.60 & 13.80 & 78.21 \\
\hline & & 89 & 10 & 5.70 & 48.71 & 1.51 & 12.50 & 12.93 & 83.31 \\
\hline & \multirow[t]{2}{*}{ Post } & 51 & 5 & 4.58 & 49.28 & 1.29 & 12.41 & 12.66 & 75.25 \\
\hline & & 51 & 10 & 6.99 & 44.01 & 1.32 & 10.13 & 10.22 & 83.52 \\
\hline
\end{tabular}

pre Premordanting, post postmordanting, Control silk dyed without mordant, undyed fabric without mordant and dye 


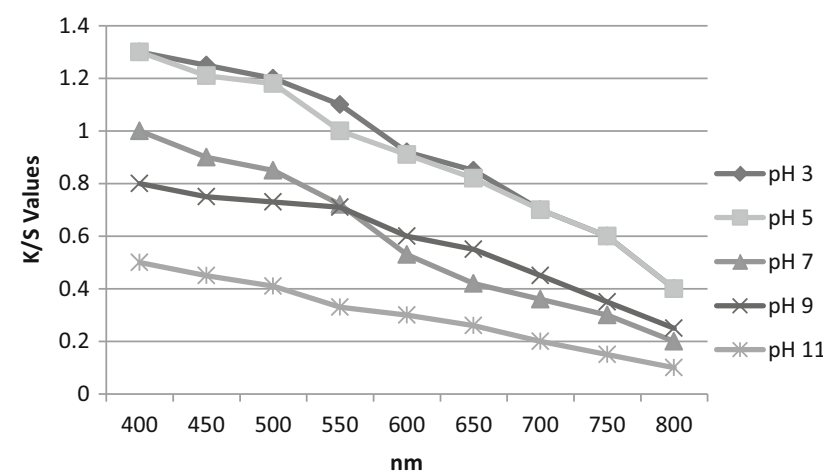

Fig. 7 Effect of dye bath $\mathrm{pH}$ on color strength of dyed silk fabrics

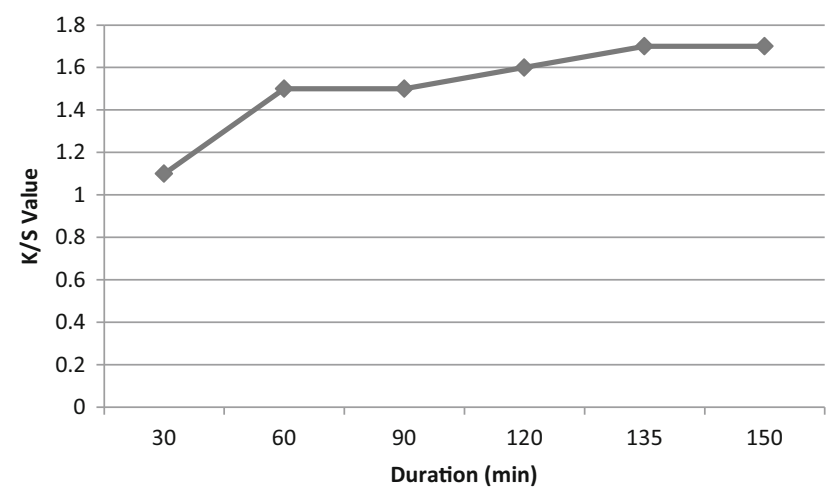

Fig. 8 Effect of dyeing time on the color strength of silk fabrics

\section{Determination of Color Coordinates of Dyed Samples}

The colorimetric data (Table 1) indicates the depth and natural tone of dyed and mordanted samples. K/S value of the dyed samples shows that use of mordants considerably increased dye absorption leading to higher $\mathrm{K} / \mathrm{S}$ values in the case of mordanted samples than in un-mordanted

Table 3 Antibacterial activity against E. coli of silk samples (10\%) dyed with Vitex negundo leaves extract with and without mordants after dyeing and laundering

\begin{tabular}{|c|c|c|c|c|}
\hline \multirow[t]{2}{*}{ Mordants } & \multirow[t]{2}{*}{ Method } & \multirow[t]{2}{*}{ Mordant (\%) } & \multicolumn{2}{|c|}{ Bacterial reduction $(\%)$} \\
\hline & & & After dyeing & After laundering \\
\hline Control & - & - & 70.8 & 70.2 \\
\hline \multirow[t]{4}{*}{ Alum } & \multirow[t]{2}{*}{ Pre } & 5 & 80.3 & 80.1 \\
\hline & & 10 & 82.5 & 80.3 \\
\hline & \multirow[t]{2}{*}{ Post } & 5 & 80.1 & 78.4 \\
\hline & & 10 & 82.6 & 80.9 \\
\hline \multirow[t]{4}{*}{ Tannic acid } & \multirow[t]{2}{*}{ Pre } & 5 & 88.5 & 87.1 \\
\hline & & 10 & 95.5 & 94.0 \\
\hline & \multirow[t]{2}{*}{ Post } & 5 & 89.6 & 87.9 \\
\hline & & 10 & 96.3 & 95.2 \\
\hline \multirow[t]{4}{*}{ Tartaric acid } & \multirow[t]{2}{*}{ Pre } & 5 & 81.0 & 78.6 \\
\hline & & 10 & 82.8 & 81.0 \\
\hline & \multirow[t]{2}{*}{ Post } & 5 & 80.5 & 78.9 \\
\hline & & 10 & 81.5 & 80.0 \\
\hline
\end{tabular}

Table 2 Fastness properties for silk fabric dyed with Vitex negundo leaves extract

\begin{tabular}{|c|c|c|c|c|c|c|c|}
\hline \multirow[t]{2}{*}{ Mordant } & \multirow[t]{2}{*}{ Method } & \multirow[t]{2}{*}{ Mordant $\%$} & \multirow[t]{2}{*}{ Light } & \multicolumn{2}{|c|}{ Wash fastness } & \multicolumn{2}{|c|}{ Rubbing fastness } \\
\hline & & & & $\mathrm{CC}$ & $\mathrm{CS}$ & Dry & Wet \\
\hline Control & - & - & 2 & 3 & 4 & 5 & 4 \\
\hline \multirow[t]{4}{*}{ Alum } & \multirow[t]{2}{*}{ Pre } & 5 & 3 & 3 & 5 & 5 & 4 \\
\hline & & 10 & 4 & 3 & 5 & 5 & 5 \\
\hline & \multirow[t]{2}{*}{ Post } & 5 & 4 & 4 & 5 & 5 & 5 \\
\hline & & 10 & 4 & 4 & 5 & 5 & 5 \\
\hline \multirow[t]{4}{*}{ Tannic acid } & \multirow[t]{2}{*}{ Pre } & 5 & 3 & 3 & 5 & 5 & 4 \\
\hline & & 10 & 3 & 4 & 5 & 5 & 5 \\
\hline & \multirow[t]{2}{*}{ Post } & 5 & 4 & 3 & 5 & 5 & 5 \\
\hline & & 10 & 4 & 4 & 5 & 5 & 5 \\
\hline \multirow[t]{4}{*}{ Tartaric acid } & \multirow[t]{2}{*}{ Pre } & 5 & 3 & 3 & 5 & 5 & 5 \\
\hline & & 10 & 3 & 4 & 5 & 5 & 5 \\
\hline & \multirow[t]{2}{*}{ Post } & 5 & 4 & 3 & 5 & 5 & 5 \\
\hline & & 10 & 4 & 4 & 5 & 5 & 5 \\
\hline
\end{tabular}

$c c$ Color change, $c s$ color staining, control silk dyed without mordants 
samples. It can be attributed to the complex formation between fabric, mordant and dye. Post-mordanted samples of both alum and tartaric acid were found to have more prominent effect on colour strength than others. From $a^{*}$ and $\mathrm{b}^{*}$ the color gamut of silk samples dyed with $V$. negundo indicates a red yellow zone. The $\mathrm{L}^{*}$ values were lower in the case of all post-mordanted samples corresponding to darker shades, whereas higher in the case of $5 \%$ pre-mordanted samples.

\section{Fastness Testing}

Color fastness properties (light, washing and rubbing) of the $V$. negundo dyed silk fabric samples are given in

Table 4 Antibacterial activity against Staphylococcus aureus of silk samples $(10 \%)$ dyed with Vitex negundo leaves extract with and without mordants after dyeing and laundering

\begin{tabular}{|c|c|c|c|c|}
\hline \multirow[t]{2}{*}{ Mordants } & \multirow[t]{2}{*}{ Method } & \multirow[t]{2}{*}{ Mordant (\%) } & \multicolumn{2}{|c|}{ Bacterial reduction $(\%)$} \\
\hline & & & After dyeing & After laundering \\
\hline Control & - & - & 65.1 & 64.0 \\
\hline \multirow[t]{4}{*}{ Alum } & \multirow[t]{2}{*}{ Pre } & 5 & 75.6 & 75.6 \\
\hline & & 10 & 77.1 & 77.0 \\
\hline & \multirow[t]{2}{*}{ Post } & 5 & 79.1 & 78.2 \\
\hline & & 10 & 80.8 & 80.5 \\
\hline \multirow[t]{4}{*}{ Tannic acid } & \multirow[t]{2}{*}{ Pre } & 5 & 84.6 & 83.6 \\
\hline & & 10 & 85.7 & 85.1 \\
\hline & \multirow[t]{2}{*}{ Post } & 5 & 86.4 & 86.0 \\
\hline & & 10 & 87.9 & 86.0 \\
\hline \multirow[t]{4}{*}{ Tartaric acid } & \multirow[t]{2}{*}{ Pre } & 5 & 80.0 & 78.5 \\
\hline & & 10 & 81.5 & 81.3 \\
\hline & \multirow[t]{2}{*}{ Post } & 5 & 80.2 & 80.0 \\
\hline & & 10 & 81.8 & 81.0 \\
\hline
\end{tabular}

Table 2. All the samples dyed with $V$. negundo exhibited moderate to good light-fastness i.e., 3-4. The dyed samples showed moderate to good wash-fastness ratings ranging from 3 to 4 on gray scale for change in colour and no staining on adjacent fabrics were observed. The wet rubfastness of the dyed samples was found to be between 4 and 5 and dry rub-fastness ratings were 5 .

\section{Antibacterial Properties}

The antibacterial activity of mordanted and unmordanted dyed silk fabrics against $E$. coli and $S$. aureus was assessed. Tables 3 and 4 show the antibacterial results of samples dyed using $V$. negundo with $10 \%$ dye concentration after dyeing, after laundering and exposure to light. The majority of natural dyes need a mordant in the form of a metal salt to create an affinity between the fiber and the pigment. These metals form a ternary complex on one side with the fiber and on the other side with the dye. Such a strong coordination tendency enhances the interaction between the dye and the fiber, resulting in higher dye uptake.

The antibacterial activity of dyed samples has increased after mordanting. Regardless of the nature of the mordant used in dyeing, samples with different mordant treatments showed different levels of improvement in antibacterial activity. By applying pre and post-mordant treatment, the antibacterial activity of the dyed samples not only increased, but also remained stable after laundering. The antibacterial results also revealed that dyed fabrics after laundering have almost similar antibacterial activity against gram positive and gram negative bacteria. The bacterial inhibition may be attributed to the active substances present within the coloring matter as also to the well known fact that the metallic salts used as mordants exhibit toxic effects against the pathogens. Among the

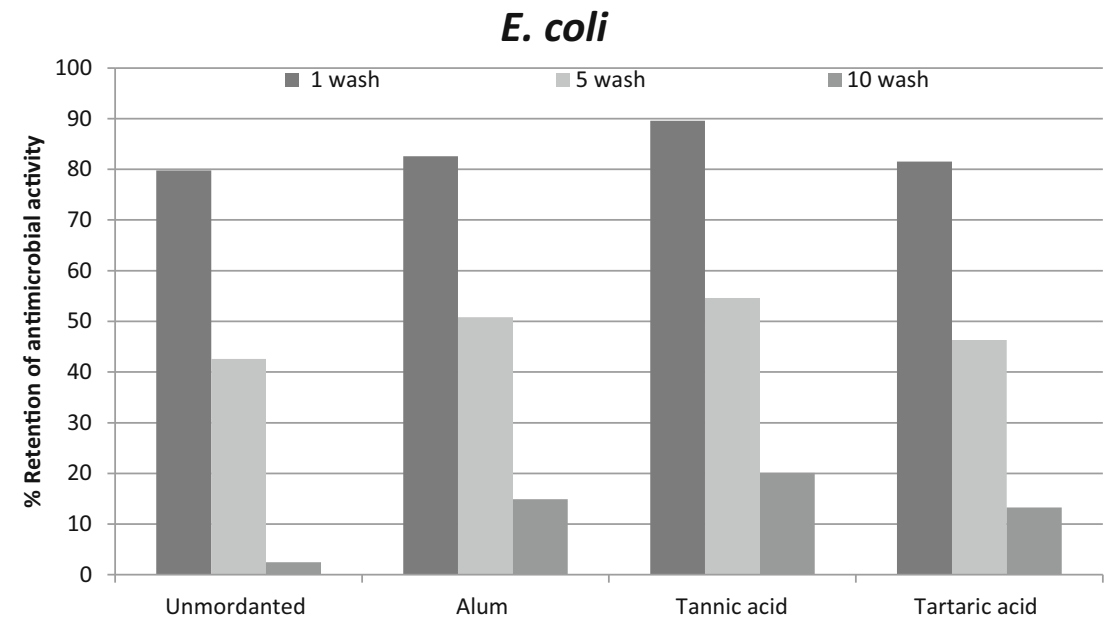

Fig. $9 \%$ Retention of antimicrobial activity to washing against E. coli 
Fig. $10 \%$ Retention of antimicrobial activity to washing against $S$. aureus

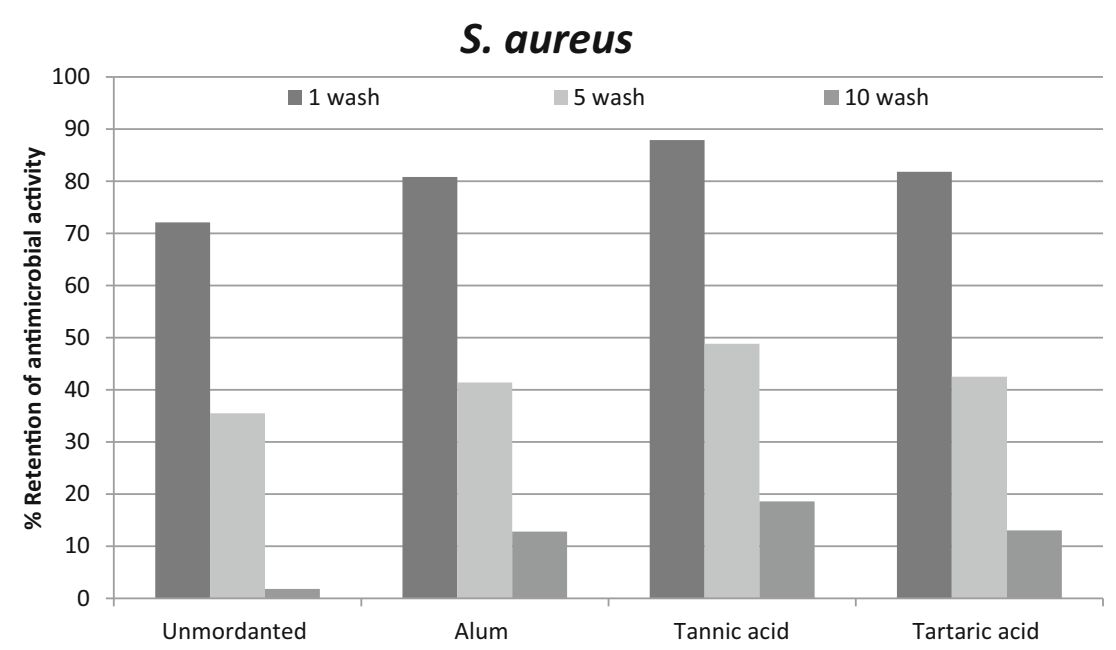

Table 5 Concentration of red listed chemicals in the extracted dye

\begin{tabular}{lll}
\hline Parameters & Permissible range $(\mathrm{ppm})$ & Dye $(\mathrm{ppm})$ \\
\hline Heavy metals & & \\
Arsenic & 0.02 & 0.001 \\
Cadmium & 0.1 & $\mathrm{Ab}$ \\
Chromium & 1.0 & 0.02 \\
Cobalt & 1.0 & $\mathrm{Ab}$ \\
Copper & 10 & 0.25 \\
Lead & 0.08 & $\mathrm{Ab}$ \\
Mercury & 0.02 & $\mathrm{Ab}$ \\
Nickel & 1 & 0.01 \\
Zinc & 10 & 0.02 \\
Pesticides & - & $\mathrm{NT}$ \\
Banned aryl amines & - & $\mathrm{NT}$ \\
\hline
\end{tabular}

$N T$ not traceable, $A b$ absent

three mordants, tannic acid showed highest antibacterial activity against both bacteria. Many metallic salts are shown to inhibit the growth of microorganisms or destroy them at very low concentrations. Metal may have toxic effects either in its free state or in metallic compounds. The mechanism of metal antibacterial action is suggested to be either through protein binding or formation of reactive oxygen species [15].

\section{Wash Durability of Antimicrobial Activity}

Figures 9 and 10 represent the durability of antimicrobial activity in terms of $\%$ retention of microbial activity after washing. Microbial \% reduction of dyed silk fabric samples were examined over three different launderings viz., 1, 5 and 10. Silk fabric samples mordanted with tannic acid were found to be most effective against both tested microbes. After 5 washing cycles microbial activity was reduced to $<45 \%$ of the initial stage against both bacteria.

\section{Analysis of Elements in Dyed Samples}

The metal content in dyed silk samples is shown in Table 5. Results showed the extremely low quantities of heavy metals extracted from the $V$. negundo leaves extract. As the concentrations are much below the stipulated limits the extracted dye can be considered eco-friendly.

\section{Conclusion}

In the present study natural dye extracted from the leaves of $V$. negundo was applied on silk fabrics and the performance attributes of the dyed fabrics with respect to colour strength, colour fastness and antibacterial activity was assessed. All the dyed silk samples exhibited good colour fastness to washing, rubbing and acceptable color-fastness to light; therefore, the colorant can be an alternative to synthetic dyes. Also the dyed samples exhibited antibacterial activity against two bacteria gram-positive bacterium, S. aureus and gram-negative bacterium $E$. coli. It was found that the extracted dye is safe and eco-friendly as the red listed chemicals are either absent or their concentration is much below the stipulated limits. The data generated from the present study should encourage the economic viability of natural dye production to be considered on a commercial scale. This would help towards utilization of plant waste; to uplift the socio-economic growth in rural areas; and to serve further the global demand for dyed textiles using safe and eco-friendly dyes from natural sources. 
Acknowledgments The authors are thankful to the Bangalore University, Bangalore for providing the financial support under interdisciplinary collaborative research fund.

\section{References}

1. S. Ratnapandian, S.M. Fergusson, L. Wang, Application of Acacia natural dyes on cotton by pad dyeing. Fibers Polym. 13(2), 206 (2012)

2. M. Mirjalili, K. Nazarpoor, L. Karimi, Eco-friendly dyeing of wool using natural dye from weld as co-partner with synthetic dye. J Clean. Prod. 19(2011), 1045 (2011)

3. V. Narayana swamy, K.N. Ninge gowda, R. Sudhakar, Extraction and application of natural dye from byproduct of Psidium guajava L leaves. J. Natl. Fibers 10(2013), 257 (2013)

4. Y. Choia, H. Jeonga, J. Lee, Antioxidant activity of methanolic extracts from some grains consumed in Korea. Food Chem. 103, 130 (2007)

5. The wealth of India: Raw materials publication \& Information Directorate, CSIR, New Delhi, vol. X, p 520 (1976)

6. M.G. Dharmasiri, J.R. Jayakody, G. Galhena, S.S. Liyanage, W.D. Ratnasooriya, anti-inflammatory and analgesic activities of mature fresh leaves of Vitex negundo. J Ethnopharmacol 87(2-3), 199 (2003)

7. R.P. Samy, S. Ignacimuthu, A. Sen, Screening of 34 Indian Medicinal plants for antibacterial property. J. Ethnopharmacol. 62(2), 173 (1998)
8. V.R. Tandon, Medicinal uses and biological activities of Vitex negundo. Natl. Prod. Radiance 4(3), 162 (2005)

9. P.L. Ladda, C.S. Magdum, Vitex negundo Linn: ethnobotany, phytochemistry and pharmacology - a review. Int. J. Adv. Pharm. Biol. Chem. 1(1), 111 (2012)

10. A.K. Meena, U.S. Niranjan, M.M. Rao, M.M. Padhi, R. Babu, A review of the important chemical constituents and medicinal uses of Vitex genus. Asian J. Tradit. Med. 6(2), 54 (2011)

11. R. Singh, A. Jain, S. Panwar, D. Gupta, S.K. Khare, Antimicrobial activity of some natural dyes. Dyes Pigm. 66, 99 (2005)

12. S. Baliarsingh, A.K. Panda, J. Jena, T. Das, N.B. Das, Exploring sustainable technique on natural dye extraction from native plants for textile: identification of colorants, colourimetric analysis of dyed yarns and their antimicrobial evaluation. J. Clean. Prod. 37(2012), 257 (2012)

13. V. Narayana Swamy, K.N. Ninge Gowda, R. Sudhakar, Dyeing properties of natural dye Syzygium cuminii on silk. J. Inst. Eng. India Ser. E 95(1), 11 (2014)

14. H. Lokeshwari, G.T. Chandrappa, Impact of heavy metal contamination of Bellandur Lake on soil and cultivated vegetation. Curr. Sci. 91(5), 622 (2006)

15. H.F. Mansour, A.A. Haroun, Ultrasonic efficiency on the photofading of Madder dyed silk using egg albumen and aluminium ions chelating. in The 6th International Conference of Textile Research Division, Cairo, Egypt: National Research Centre 15-67 (2009) 